\title{
thumanidades
}

Revista Humanidades

ISSN: 2215-3934

humanidades@ucr.ac.cr

Universidad de Costa Rica

Costa Rica

\section{La filosofía del troleo: una revisión interpretativa}

González de Requena Farré, Dr. Juan Antonio

La filosofía del troleo: una revisión interpretativa

Revista Humanidades, vol. 11, núm. 2, 2021

Universidad de Costa Rica, Costa Rica

Disponible en: https://www.redalyc.org/articulo.oa?id=498066660009

DOl: https://doi.org/10.15517/h.v11i2.47680

\section{(c) $(1) \Theta$}

Esta obra está bajo una Licencia Creative Commons Atribución-NoComercial-SinDerivar 3.0 Internacional. 
Desde los estudios étnicos, culturales, de género y ambientales

\title{
La filosofía del troleo: una revisión interpretativa
}

\author{
The Philosophy of Trolling: an Interpretive Review \\ Dr. Juan Antonio González de Requena Farré \\ Universidad Austral de Chile, Puerto Montt, Chile \\ jgonzalez@spm.uach.cl \\ iD https://orcid.org/0000-0002-4296-2211
}

DOI: https://doi.org/10.15517/h.v11i2.47680

Redalyc: https://www.redalyc.org/articulo.oa?

$\mathrm{id}=498066660009$

Recepción: 19 Abril 2021
Aprobación: 25 Junio 2021

\section{Resumen:}

El creciente interés de las ciencias humanas y sociales por el fenómeno del troleo en Internet se ha enfocado en su conceptualización, modalidades, explicaciones y trasfondos culturales. Bajo la premisa de que el troleo constituye una práctica transdiscursiva, disruptiva, delusoria y autorreplicante, este artículo explicita algunas de las tradiciones históricas y marcos culturales de comprensión bajo los cuales se concibe el fenómeno en la bibliografía. Metodológicamente, se llevó a cabo una revisión bibliográfica interpretativa de un corpus seleccionado por conveniencia. Desde la perspectiva de los guiones simbólicos y prácticas culturales tradicionales que actualiza el troleo, cabe asociarlo con la privatización de la bufonería, la universalización de la calumnia, la democratización de la censura, la virtualización del linchamiento y la hibridación del conflicto. Se puede concluir que, más que posibilitar un tipo de práctica culturalmente transgresora y subversiva, el troleo constituiría una exacerbación tóxica del pánico moral y la ironía vanidosa.

Palabras ClaVE: Internet, problemas sociales, control social, conflicto social.

\begin{abstract}
:
The growing interest of social sciences and humanities in the phenomenon of Internet trolling has focused on its conceptualization, modalities, explanations and cultural backgrounds. Under the premise that trolling constitutes a transdiscursive, disruptive, delusional and self-replicating practice, this article aims to make explicit some of the historical traditions and cultural frameworks of understanding under which the phenomenon is conceived in the bibliography. Methodologically, an interpretative bibliographic review of a corpus selected for convenience was carried out. From the perspective of the symbolic scripts and traditional cultural practices that trolling updates, it can be associated with the privatization of buffoonery, universalization of slander, democratization of censorship, lynching virtualization and hybridization of conflict. It can be concluded that, rather than enabling a type of culturally transgressive and subversive practice, trolling would constitute a toxic exacerbation of moral panic and vain irony.
\end{abstract}

KEYWORDS: Internet, social problems, social control, social conflict.

\section{INTRODUCCIÓN}

En los medios de comunicación digitales, la publicación de contenidos suele ir acompañada por toda una avalancha de comentarios que hacen posible reconocer ciertas prácticas y estilos discursivos contemporáneos. Tras la publicación de una noticia política, resulta predecible una prolífica adición de comentarios; de esas opiniones, solo una mínima parte constituirán aportaciones genuinas e informadas a una posible discusión en curso. La mayoría de las intervenciones consistirán en movimientos discursivos como los siguientes: exabruptos contra la ideología del periodista o del medio de comunicación; ataques personales a representantes políticos actuales o pasados; soflamas conspiratorias contra el sistema y otras ideologías; réplicas insultantes dirigidas a otros participantes (a su ideología, su persona, su familia, su procedencia o su forma de escribir); respuestas desencajadas a los insultos ya proferidos; repetición de opiniones irrelevantes, memes y enlaces a contenidos ajenos a la discusión; seguramente, muchas carcajadas transcritas de modos variables. 
Asimismo, si la noticia tuviera algún contenido social, cabría esperar, además, la manifestación provocativa de indiferencia hacia la suerte ajena o la expresión de resentimiento antisistema; la reproducción de prejuicios socioeconómicos, culturales o de género y la multiplicación de descalificaciones racistas, clasistas o sexistas; atribuciones conspiratorias de responsabilidad por la situación presente; muchos insultos y descalificaciones, así como réplicas a las descalificaciones y, por último, salidas por la tangente. En el caso específico de las noticias con contenido personal, todos los movimientos discursivos ya señalados destilarían una mayor odiosidad, resentimiento y crispación personal; como consecuencia, se intensificarían las burlas, mofas e insultos. De hecho, un buen número de involucrados en estas prácticas recurren a nombres ficticios, imágenes no referenciales o localizaciones inverosímiles; algunos de los participantes del foro -no solo los provocadores- atraen oleadas reiteradas de cuestionamientos y descalificaciones.

Este tipo de comportamiento comunicativo tan desconcertante no se restringe a los foros de comentarios de los medios digitales, sino que también se reitera en las redes sociales masivas (por ejemplo, Twitter, YouTube, Facebook), o bien en canales y foros más exclusivos (como los de Reddit, 4chan o ciertos juegos en línea). No parece tratarse solo de una práctica lúdica de adolescentes ociosos o jóvenes problemáticos ni de reducidas comunidades virtuales de jugadores, nativos digitales o fanáticos de la industria del entretenimiento. Como se observa en los foros de noticias, también convoca a adultos de distintas edades dispuestos a perder su tiempo en el tráfago de exabruptos, descalificaciones, arengas, sarcasmos, consignas, prejuicios, bulos y, eventualmente, alguna opinión personal medianamente sensata.

Incluso los personajes públicos más o menos relevantes -ya se trate de rostros de la industria del entretenimiento (deportistas, actores, modelos, etc.) o de representantes y autoridades políticas- se han involucrado en este formato de comunicación digital desprovisto de foco atencional, filtro informativo, selección de fuentes, etiqueta o cortesía, por no decir nada acerca de su racionalidad argumentativa, relevancia cognitiva, prudencia normativa o reflexividad crítica. Algunos tópicos de la agenda pública local, nacional e internacional se despachan y se discuten antes en estos formatos de comunicación digitalmente mediada, a través de las redes sociales oficiales o personales de ciertos representantes políticos o colectivos políticos, para luego ser recogidos en los medios de comunicación tradicionales (en virtud del impacto producido en las redes sociales). Finalmente, esos temas retornan a las cámaras políticas y al foro eminentemente público, donde con cada vez mayor frecuencia se reproducen puestas en escena - la tan manida performance- muy cercanas a las consignas disruptivas, descalificadoras y virales de las redes sociales.

Tampoco parece tratarse de una forma de acción política espontáneamente organizada desde abajo hacia arriba, pues algunas formaciones políticas y gobiernos autoritarios se sirven sistemáticamente de estas prácticas comunicativas en Internet para censurar a los opositores, destruir la reputación de otros actores políticos o representantes sociales y estigmatizar al enemigo. Ni siquiera puede decirse que estas prácticas de comunicación, digitalmente mediadas, sean solo virtuales y consistan únicamente en algún tipo de violencia simbólica. Frecuentemente, la descalificación personal, la humillación concertada, la destrucción de la reputación y el acallamiento de otras opiniones en las redes prosiguen y se concretan, por otros medios, en la realidad cotidiana y en la vida diaria de los afectados. Las consecuencias de estas prácticas de comunicación digitalmente mediadas son, por tanto, muy reales e inciden en la intimidad de las personas, en la calidad de los vínculos comunitarios y en la representatividad de la esfera pública.

Algunas de estas prácticas comunicativas digitalmente mediadas suelen asociarse a lo que, en la cultura popular y en las discusiones académicas, se designa ampliamente como troleo (trolling). Cuando se considera que el troleo se ha convertido en una práctica generalizada y un estilo cultural hegemónico, cabe preguntarse por los repertorios culturales y tradiciones históricas que podrían expresarse o canalizarse a través del fenómeno. Al fin y al cabo, los lenguajes culturales y estilos colectivos no surgen de la nada ni se crean desde cero, sino que involucran transformaciones y traducciones de léxicos, prácticas y sensibilidades históricamente sedimentadas, cuyas funciones culturales y guiones simbólicos se reapropian, reinventan, transgreden $y$, a veces, trascienden. 
¿Cuáles son las prácticas culturales y tradiciones históricas evocadas por el troleo en la discusión contemporánea? ¿Cómo se enmarca ese fenómeno en una perspectiva histórica de larga duración que reconozca sus características diferenciales? Para responder semejantes interrogantes, en este estudio se realizó una revisión bibliográfica integrativa (Snyder, 2019) e interpretativa (Fernández y Buela, 2009) que se enfocó en proveer un marco de comprensión de cierta problemática teórica, mediante la sistematización y la crítica de un corpus heterogéneo de fuentes escogidas por conveniencia.

\section{ANTECEDENTES TEÓRICOS}

\subsection{Concepciones del troleo}

Ciertamente, el troleo constituye un fenómeno complejo y multiforme, en la medida en que las definiciones del concepto son difusas y no parecen establecerse límites acotados con respecto a otras formas de comportamiento digital antisocial (como el ciberacoso, por ejemplo). Además, las manifestaciones del troleo dependen, en gran medida, del contexto y no siempre pueden extrapolarse más allá de cierta comunidad de usuarios (pues no son lo mismo los comentarios en medios digitales o el sabotaje de las entradas de Wikipedia) (Cruz et al., 2018, pp. 16-17).

En los ambientes de la comunicación digitalmente mediada (como Reddit o Wikipedia), el troleo se asocia al incordio deliberado, astuto y encubierto de otras personas en los diálogos y foros en Internet. No se trataría solo de insultar o bombardear con mensajes, sino de generar controversia mediante mensajes provocativos intencionados, contenidos irrelevantes y ataques personales, con la finalidad de molestar a la gente, interrumpir la discusión y divertirse así (Fichman y Sanfilippo, 2016, p. 7). Por otra parte, en algunas definiciones académicas del troleo se privilegian las concepciones y discusiones de los propios usuarios; es el caso de la caracterización del trol propuesta por Claire Hardaker (2010), quien vincula el fenómeno a una forma de descortesía comunicativa engañosa, disruptiva y agresiva:

Un troleador [troller] es un usuario de CMC [comunicación mediada por computadores] que construye la identidad de que desea sinceramente ser parte del grupo en cuestión, lo que incluye profesar o transmitir intenciones pseudo-sinceras, pero cuya intención(es) real(es) es (son) causar interrupción y/o desencadenar o exacerbar el conflicto con el propósito de divertirse (p. 237).

En ese sentido, las definiciones académicas del troleo suelen vincularlo con comportamientos agresivos, descorteses, hostiles y manipuladores en la comunicación digital. Además, las conductas del trol se caracterizan por la provocación y el engaño, sin otro propósito que generar disrupciones comunicativas y desencadenar reacciones arrebatadas (Fichman y Sanfilippo, 2016, p. 25). Algunas investigaciones sobre la dimensión pragmática del troleo basadas en las perspectivas de los usuarios y las audiencias digitales eluden las caracterizaciones demasiado amplias y negativas (como si solo fuese una comunicación digital de mensajes disruptivos y hostiles para generar conflicto), y privilegian particularmente ciertos rasgos como condiciones necesarias de este fenómeno en interacciones que involucran a un emisor, un receptor y una audiencia. Por un lado, se ejerce el engaño digital sobre el objetivo (la falsificación de la identidad del emisor o del contenido del mensaje, la charlatanería, cierta apariencia engañosa de sinceridad, etc.). Por otro lado, concurre el entretenimiento humorístico, la diversión de los participantes y, sobre todo, de los propios troles, mediante comunicaciones provocativas y no necesariamente ofensivas, que ridiculizan básicamente la ingenuidad de quien pica el anzuelo (Dynel, 2016).

El cariz benévolo e inofensivo del troleo ha sido defendido por las investigaciones que le atribuyen a esta práctica un efecto constructivo para el fortalecimiento de la cohesión grupal y de los lazos compartidos entre los participantes de las comunidades en línea, al movilizar a los integrantes en defensa del endogrupo virtual y generar alianzas contra los intrusos (Hopkinson, 2013). También, han valorado el troleo aquellas 
investigaciones que enfatizan la capacidad del fenómeno para establecer formas productivas de provocación y respuesta cáustica, introducir formatos agonísticos de participación pública y posibilitar expresiones contestarias de ciudadanía digital, marcadas por un tenor intensamente afectivo y por el conflicto pluralista (McCosker, 2014). En algunos casos, se ha llegado a sostener que el troleo constituiría una práctica transgresora y una provocación subversiva, consistente en trastocar los protocolos de la comunicación humana y las reglas establecidas. De este modo, se desafiaría contra-hegemónicamente a las ideologías dominantes, a través de la mofa carnavalesca, el arrebato apasionado y la ridiculización de los discursos oficiales (Mylonas y Kompatsiaris, 2021).

Ahora bien, en algunos estudios sobre el empleo cotidiano del término entre usuarios, se remarcan aquellos aspectos negativos del troleo, como el acoso colectivo, la intención maliciosa de provocar a otros usuarios, o bien los ataques basados en la identidad étnica, racial o de género. De esta forma, se podría concluir que esta práctica de acoso identitario contribuye a la reproducción del racismo, del sexismo y, en general, de las desigualdades sociales (Ortiz, 2020). Asimismo, hay investigaciones que destacan el carácter simplificador, impulsivo e incivil de las prácticas de troleo en las redes sociales -y su extrapolación a las protestas sociales en general-, con la consiguiente erosión de la discusión democrática, pues se espectaculariza el disenso arrebatado y se generalizaría una retórica del resentimiento, en la cual se enrarece y desvirtúa la opción del disentimiento público constructivo (Asenas y Hubble, 2018).

Desde una perspectiva jurídica, se ha intentado tipificar distintos niveles de gravedad en la actividad del troleo. En el grado más leve, se daría la mofa esporádica y discontinua que puede agravarse si concurren las ofensas groseras y las amenazas. En segundo lugar, está el nivel táctico del troleo, reiterado y sin arrepentimiento que se agrava si hay acoso y angustia. En tercer lugar, hay un grado estratégico en que el troleo resulta persistente y puede asociarse a formas más severas de acoso y malestar. Finalmente, se da la modalidad más extrema de troleo de dominación que involucra planificación sistemática, individualización del objetivo y -en los casos más graves- formas muy ofensivas y amenazadoras de asedio e intimidación (Bishop, 2013, pp. 312-316).

Bajo este punto de vista normativo del campo legal, hay todo un repertorio de características que se le pueden atribuir al troleo: el aspecto antisocial, en la medida en que se quebranta la cohesión social; la intención deliberada de dañar, al molestar, ofender o humillar a personas y colectivos, mediante comentarios extremos; el ánimo de engañar y despistar; el carácter arbitrario de los comentarios que convierte en objetivo del abuso a cualquiera con presencia en los medios sociales; el aspecto extremo de la expresión y contenido para generar así mayor ofensa y consternación; la victimización personal y el perfilamiento de las víctimas sobre quienes volcar los bulos, difamaciones y comentarios cáusticos; el ejercicio de cierta dominación por medio de la ofensa y la amenaza; el efecto contagioso y acumulativo del acoso a la víctima; la gratificación adictiva al ejercer el troleo; la experticia digital para crear identidades y perfiles; por último, el anonimato, mediante el recurso a seudónimos o avatares, para construir un personaje ofensivo, escenificar cierto dominio grupal y aumentar el desamparo de la víctima (Noble, 2017, pp. 114-118).

En gran medida, la consideración positiva o negativa del troleo parece depender del contexto y asunto de la comunicación digital, de modo que la categoría de trol se convierte en un significante disputado y negociado en el curso de las interacciones en línea. Se trata de un término cuyo significado es construido conjuntamente por los participantes, según las necesidades retóricas del contexto. Así, si quienes trolean son extraños que no participan regularmente en cierta comunidad digital, suelen ser percibidos negativamente como transgresores de la comunicación en línea y de las normas grupales (aunque algunos participantes puedan idealizar nostálgicamente cierto troleo travieso reconocible e inofensivo). Por otro lado, si los troles pertenecen al endogrupo de una comunidad digital, son percibidos más positivamente, como una forma de troleo aceptable y un modo legítimo de sanción, en el caso de que contribuyan a desenmascarar a los indeseables troles maliciosos, es decir, al trolear a los troles (Coles y West, 2016). 
Como han puesto de manifiesto algunas investigaciones desde la perspectiva de los usuarios, la mayoría de la gente consideraría el troleo como una forma de comportamiento digital deliberadamente insultante y ofensiva, dirigida a provocar reacciones emocionales intensas. En todo caso, la percepción y definición del fenómeno depende de la experiencia en Internet: quienes no han participado del troleo tienden a significarlo como una actividad insultante u ofensiva y la asocian al malestar y el enojo; los que trolean lo vinculan a una actividad divertida, jocosa y bromista; los que han sido troleados y también trolean remarcan la camaradería humorística y la diversión compartida; quienes no han sido troleados relacionan el troleo con el cibermatonaje y el ciberacoso (March y Marrington, 2019).

\subsection{Modalidades del troleo}

Sin duda, las dificultades a la hora de definir y valorar el troleo pueden atribuirse a los distintos tipos de prácticas categorizadas y a las variaciones históricas del fenómeno. Quizá, en la década de los noventa, el término troleo remitía a cierto ritual compartido de iniciación en algunas comunidades virtuales, en virtud del cual se incordiaba humorísticamente a los novatos incautos e ingenuos, solo para divertirse en común y reírse un rato, pero también para reforzar los vínculos entre la comunidad de participantes. No obstante, desde finales de la primera década del siglo XXI, con la popularización del significante troleo y la respuesta de pánico moral (esto es, la reacción masiva y desproporcionada de enjuiciamiento, culpabilización y demonización) en los medios de comunicación social, el fenómeno se ha asociado a una forma de acoso hostil, abuso humillante y mofa transgresora - habitualmente sobre personas ajenas a cierta comunidad o de otros grupos identitarios-, con el único propósito del gozo individual del trol a expensas de su víctima (como ocurre en la incendiaria ofensa grosera dirigida a personas vulnerables e, incluso, fallecidas) (Bishop, 2014, pp. 9-10).

En todo caso, el repertorio de caracteres vinculados al fenómeno cubriría un arco mucho más amplio de tipos de troles, como ha sostenido Bishop (2014). En algunos troles destaca el odio y el gusto por provocar e incitar, sin ningún beneficio para los otros usuarios. Entre estos haters, están los vengadores que pretenden desenmascarar a otros, iconoclastas empeñados en contradecir la cosmovisión de los demás y develar su propia verdad, así como pesados resentidos que solo persiguen dañar a otros por gusto. Un segundo tipo de trol lo encarnan los usuarios cuyo ánimo es provocar a los demás y reírse de ellos para llamar su atención. Incluye a los participantes que publican de manera condescendiente puntos de vista admitidos por la audiencia, pero también a quienes ejercen cierta autocrítica para ganarse la empatía ajena, o bien a quienes conquistan la confianza de otros para manipularlos. Además, otro tipo de trol solo perseguiría ser parte de la conversación digital, aunque sus contribuciones no sean relevantes ni útiles (al tratarse solo de contenidos ajenos al foco o humoradas). Por último, existiría toda una categoría de mirones que solo pretenden observar las participaciones ajenas para lanzar, en el momento oportuno, mensajes provocativos, ya sea mediante una vigilancia silenciosa, al procurar el divertimento entretenido de la comunidad virtual, o bien al dar cuenta de usuarios inexpertos y novatos incautos (Bishop, 2014, pp. 11-12).

Además de clasificar a los troles por el tipo de personaje que encarnan, cabe categorizar los tipos de troleo de acuerdo a su contenido. Así, hay un troleo de páginas memoriales dedicadas a personas fallecidas o a las víctimas de alguna tragedia. Además, existe un troleo ideológico, el cual está habitualmente vinculado al activismo y la protesta digitales. Se da el troleo por simple diversión, consistente en el sarcasmo sobre una víctima. Se puede reconocer cierto troleo desideologizado, que expone a los novatos incautos. También existe un troleo religioso, que tiene por objeto las contradicciones de algún credo religioso o alguna Iglesia. Finalmente, se encuentra el troleo político, dirigido a socavar los argumentos de otras posiciones ideológicas a través de comentarios ultrajantes y polarizadores (Fichman y Sanfilippo, 2016, p. 12).

Asimismo, en el ecosistema del troleo se podrían reconocer especies distintas con comportamientos típicos. En algunos casos se exhiben conductas como la provocación en los foros para desencadenar respuestas hostiles de otros usuarios, la manipulación o el ejercicio de ingeniería social para inducir a otros a participar en 
ciertas actividades (donaciones, voto, etc.), la insinuación y la introducción de mensajes que inician espirales persuasivas para captar adeptos, o bien el ataque personal para deslegitimar o difamar. En este ecosistema, se encuentra un tipo de troleo partisano y con fines políticos de propaganda; pero también se da el troleo masivo, rápido y continuo para confundir a la audiencia, así como aparece el troleo automatizado disruptivo que satura los canales de comunicación. No solo hay un troleo por deporte y por mera autosatisfacción del trol, sino que también existe un troleo fastidioso, para descarrilar la conversación e irritar a los demás e, incluso, un troleo distractor, mediante mensajes tangenciales que satisfacen la curiosidad. En ese sentido, en el ecosistema del troleo es posible hallar un variopinto repertorio de comportamientos hostiles: el troleo de falso abanderamiento, al hacerse pasar por integrante de un colectivo al que se quiere desacreditar; el troleo arrabalero, parecido a la reyerta callejera; el troleo de tanteo, para entrampar en la discusión enojosa; el troleo directamente insultante para desmoralizar al objetivo; el troleo aprobatorio de otros mensajes troleados. Además, aparecen en este ecosistema muy diferentes fenómenos comunicativos: el troleo amplificador que replica insistentemente mensajes de otras fuentes; el troleo por medio de intermediarios para así promover algún mensaje indirectamente; el troleo difusor de noticias falsas; el troleo que solo reproduce mensajes vacíos o irrelevantes; el troleo con contenido sospechosamente verosímil; finalmente, el troleo satírico (Berghel y Berleant, 2018, pp. 46-48).

\subsection{Explicaciones del troleo}

Aunque las motivaciones y explicaciones del troleo dependen, en cierto modo, del contexto y de los tipos de troles, algunos estudios han intentado dar cuenta de los aspectos psicológicos y sociales que concurren en este fenómeno. En su libro The Psychology of the Internet, Patricia Wallace (2016) sistematiza algunas de las claves para comprender la psicología subyacente a modalidades de agresión digital como el troleo o el ciberacoso. La sorprendente frecuencia de los insultos, el sarcasmo y la provocación verbal en las comunicaciones computacionalmente mediadas podría atribuirse a ciertos rasgos de los entornos digitales.

En primera instancia, la frustración generada por las dificultades técnicas en las redes (por ejemplo, los problemas de conectividad o navegación, los protocolos engorrosos o la lentitud de los procesos) y por la saturación indiscriminada de mensajes podría engendrar irritación y respuestas hostiles. A este factor se suma la ambigüedad de las comunicaciones en las redes, que hace bastante difícil interpretar correctamente la ironía o el sarcasmo, debido a la ausencia de indicadores no verbales y paralingüísticos. Asimismo, el anonimato también constituye un factor decisivo que conduciría a la agresión digital: cuando las personas creen que no pueden ser identificadas y que no se les atribuirá responsabilidad personal, actúan de una manera más desinhibida ante las normas y las convenciones sociales. Además, la invisibilidad o la falta de contacto visual en algunas plataformas digitales refuerza el efecto desinhibidor y, por tanto, brinda la oportunidad de exteriorizar agresiones verbales o comentarios tóxicos. Por otra parte, la distancia física entre el agresor digital y su víctima también contribuye a la desinhibición, así como envalentona a quien sabe que no puede haber venganza inmediata ni tiene presentes las señales de amenaza física. Por último, en las comunicaciones digitalmente mediadas, la agresión se vería amplificada en las redes, adquiriría una permanencia en línea que agravaría la victimización y se serviría de formatos multimedia que brindan más opciones de humillación a través de textos, imágenes y grabaciones (Wallace, 2016, pp. 97-117).

Como Wallace (2016) recuerda en su libro, algunas investigaciones han concluido que existe relación entre el troleo y cierto tipo de personalidad maligna, psicológicamente descrita a través de la llamada tétrada oscura del sadismo (tanto el disfrute directo al dañar o al humillar a otros como el gozo derivado al ser espectador del daño y humillación ajenas), la psicopatía (la ausencia de empatía afectiva y la falta de remordimiento), el maquiavelismo (la manipulación personal distanciada y calculadora) y el narcisismo vulnerable (el recurso a los otros para enmascarar la propia inseguridad y lograr una reafirmación personal defensiva) (Buckels et al., 2014; Buckels et al., 2019; March, 2019). En fin, el repertorio de factores que daría cuenta de las condiciones 
psicológicas y psicosociales del troleo parece comprender no solo los rasgos de una personalidad malévola, impulsos desviados y conductas de transgresión, o bien el simple deleite en la conducta antisocial, sino también la búsqueda de atención, la negociación y promoción del estatus social, las motivaciones ideológicas y el activismo digital para promover cambios sociales y derechos civiles o libertades personales e, incluso, las oportunidades e incentivos que brinda la tecnología para asumir desafíos e involucrarse en la innovación, la exploración y los usos transgresores (Fichman y Sanfilippo, 2016, pp. 28-47).

En todo caso, la generalización del troleo en las redes resulta indisociable de nuevas condiciones en las tecnologías de comunicación digital, de ciertas transformaciones en la esfera pública y de cambios en las sensibilidades culturales. Si se encuadra el fenómeno del troleo en el marco de los medios de comunicación social dominantes de este tiempo, podría reconocerse un desplazamiento en el discurso público, así como la irrupción de un nuevo juego de lenguaje político, según sugiere Hannan (2018). En su momento, la televisión transformó la esfera pública letrada (basada en la formación racional de la opinión y en la deliberación argumentativa), para dar paso a una cultura del entretenimiento fugaz. Actualmente, las redes sociales habrían convertido el espacio público en un patio de colegio global donde ganar popularidad, reforzar afinidades tribales y ejercer impunemente el cibermatonaje y el troleo. Así, el troleo se habría convertido en una práctica comunicativa generalizada, hegemónica y global que, incluso, trasciende a la actividad pública y contamina la vida política: la gente trolea al gobierno, a la oposición y a los distintos poderes del Estado, del mismo modo que los políticos se trolean entre sí. En consecuencia, el troleo político se convierte en un espectáculo mediático. Esta práctica se ha normalizado hasta el punto de instaurar un perturbador gobierno mediante el troleo, incluso en las relaciones internacionales (Hannan, 2018).

En este contexto, las redes sociales habrían tenido un efecto decisivo en la intoxicación y la fragmentación de la esfera pública, al desplazar el discurso público deliberativo y colectivamente responsable, para reemplazarlo por una autoafirmación absoluta del derecho individual a opinar de todo. De esa manera, se desdibujan y tambalean los límites entre el ámbito público y el privado, y se consagra la autoexpresión individual sin trabas en las redes, hasta tal punto que se habría desarrollado una cultura del comentario idiosincrático, desinhibido y beligerante. Por su parte, las plataformas virtuales consagrarían una peculiar lógica del foro, que prefiere la intervención arrebatada, el combate apasionado por la popularidad y el troleo insidioso (en lugar del argumento razonable). Así pues, se habrían visto afectadas las normas conversacionales y argumentativas tanto en línea como en la realidad cotidiana (Clucas, 2020).

Por lo demás, -según plantea Nagle (2018)- la consagración del troleo como práctica comunicativa se asocia a recientes transformaciones sociohistóricas en los estilos culturales y a conflictos culturales contemporáneos. En este sentido, en las últimas décadas se ha opacado el rol de los medios de comunicación social convencionales, pues estos ya no dictan las reglas de juego de la cultura pública ni expresan la sensibilidad hegemónica de una cultura de masas. En su lugar, habrían ido ganando terreno las sensibilidades subculturales y antisistema fraguadas en las redes sociales. También han perdido protagonismo las fuentes autorizadas y élites normativas de los viejos medios que custodiaban los márgenes del gusto popular y los estándares de la industria cultural. Como sustituto se impone el contenido digital viral, los memes y la autopublicación inmediata en las redes sociales. Más allá de la opinión pública políticamente correcta, concientizada y moralizadora, se ha ido consolidando así un estilo cultural basado en el cinismo, en el sarcasmo y en la humillación como forma de entretenimiento viral. Lo que alguna vez fueron códigos y estilos subculturales de los troles en los foros más recónditos de las redes sociales ahora disputan una esfera pública fragmentada; instauran un nuevo panóptico en el cual se impone el temor al escarnio público y han generado una furiosa reacción de cinismo antisistema que -irónicamente- puede resultar funcional a las posiciones ideológicas excluyentes, segregacionistas y autoritarias (Nagle, 2018, pp. 11-21). 


\subsection{Cuestiones de método: la transdiscursividad del troleo}

En esta revisión interpretativa se propone identificar y describir las prácticas culturales, así como las tradiciones históricas asociadas al troleo en textos contemporáneos sobre el fenómeno, para así aportar marcos interpretativos y guiones simbólicos que especifiquen la concepción de esta práctica. Semejante ejercicio de contextualización interpretativa no es impuesto desde fuera al fenómeno del troleo, sino que emerge de una comprensión inmanente de su carácter de práctica autorreplicante, disruptiva y delusoria, pero sobre todo de su configuración transdiscursiva.

En primera instancia, el troleo es caracterizado como una práctica y no como un hecho social institucional que se determine por medio de algún marco normativo o repertorio de reglas constitutivas, con las cuales se asigne colectivamente alguna función de estatus al fenómeno (Searle, 1997, pp. 44-47). No hay pues, repertorio alguno de reglas constitutivas compartidas en virtud de las cuales pueda decirse que algo cuenta como un troleo. Como modos de actividad social, las prácticas remiten a las operaciones de los usuarios, a las formas fragmentarias localizadas, situacionales e intersubjetivas de apropiación táctica y reinvención oportunista (De Certeau, 2007, pp. XLII-LI). Esto resulta particularmente patente en una actividad subcultural como el troleo, pues se trata de una operación variopinta y moldeable según los diferentes foros o plataformas en que irrumpe de forma parasitaria, paródica y disruptiva. Así pues, en lugar de privilegiar las motivaciones individuales o los rasgos de personalidad del trol, se comparte el interés de otros estudios por concebir el troleo desde un enfoque teórico centrado en las prácticas, es decir, en los plexos de actividad social que involucran patrones y procesos iterativos. Y es que las prácticas configuran las tramas de comprensiones, medios, procedimientos y competencias, a través de los cuales se despliega la dinámica de cierta comunidad digital mediante las realizaciones y reapropiaciones de los actores (Cruz et al., 2018, pp. 17-18).

En ese sentido, la aparente falta de un marco de reglas constitutivas en la práctica del troleo se vincula con su carácter disruptivo, esto es, con la desviación irrelevante o la interrupción arbitraria del curso hilado de la interacción conversacional (Hardaker, 2010, pp. 232-233). De todos modos, cabe pensar que el carácter disruptivo del troleo también concierne a la impugnación de los compromisos discursivos y vinculaciones realizativas que sostienen la acción comunicativa en el sentido en el que Habermas (1999) la concibe, esto es, como la realización de actos de habla convencionalmente regulados en los cuales se desempeñan pretensiones de validez, se realiza una oferta de entendimiento intersubjetivo y se anticipa cierto consenso comunicativo vinculante (pp. 366-391).

Algunas interpretaciones le atribuyen una eficacia performativa al troleo, pues las publicaciones de los troles no serían solo palabras o imágenes, sino que harían algo y alterarían la realidad de la persona troleada (Polak y Trottier, 2020, p. 13). Sin embargo, parece más razonable asumir que se trata de un acto perlocucionario y, por tanto, está en juego la intención -no regulada convencionalmente- de producir algo a través de lo que se publica. De esa manera, en el troleo primaría la actividad estratégica e instrumental para lograr exitosamente el propósito de fastidiar a alguien, sacar de quicio la conversación y frustrar cualquier posible entendimiento (Calvo y Aruguete, 2020, cap. 2). No en vano, los usuarios suelen considerar que, si el troleo no resulta exitoso al incordiar, no merece ese nombre (Hardaker, 2010, pp. 233-236).

Por lo demás, parte del éxito del troleo depende de la efectividad de su intención delusoria: no puede descubrirse el ocultamiento de la identidad, la falsificación de contenidos, el encubrimiento de intenciones y la sinceridad simulada, ya que no habría troleo si se evidenciase el engaño (Dynel, 2016, pp. 367-372). Asimismo, el éxito del troleo depende de su replicación, iteración y eventual viralización: una sola instancia aislada de disrupción comunicativa no constituye troleo. Como práctica iterativa y carente de otro propósito que la réplica sin finalidad, el troleo se perfila, así, como una actividad autorreplicante que potencialmente puede reproducirse de forma masiva y también puede perdurar indefinidamente en las redes sociales solo con el hecho de ser compartida (Polak y Trottier, 2020, p. 16). 
Con todo, en este estudio, el aspecto más relevante de la práctica del troleo radica en su carácter transdiscursivo. Con el concepto de transdiscursividad no solo se hace referencia al hecho de que toda práctica discursiva (así como cualquier mensaje) consigna otras voces en conjunto, remite intertextualmente a otros textos e integra interdiscursivamente elementos de distintos órdenes discursivos y tradiciones sociohistóricas (Fairclough, 1992, pp. 117-118). La transdiscursividad evoca el concepto de transtextualidad propuesto por Genette, es decir, las formas de trascendencia textual de todo texto, que no se limitan a la remisión intertextual, pues también comprenden el enmarcado paratextual, el comentario metatextual, la delimitación architextual del género, o bien las relaciones hipertextuales entre textos que versionan un mismo hipotexto anterior (Genette, 1989, pp. 9-17). Así pues, el troleo se inscribe transtextualmente en la medida en que sus publicaciones no dejan de remitir a otros textos, de enmarcar otros mensajes, comentar otras publicaciones, mimetizarse con otros discursos, transformar otros mensajes, pero también de reinscribirse atravesando cualquier trama textual consistente, coherente y simbólicamente organizada bajo algún género de discurso. No obstante, al concebir el troleo como una práctica transdiscursiva, se toman en consideración los aspectos sociales, situacionales y tácticos de la producción y recepción simbólica del discurso, más allá de los simples conjuntos textuales.

El aspecto transdiscursivo e, incluso, el aspecto multimodal del troleo (que puede integrar textos, imágenes y contenidos audiovisuales) se conjugan con su carácter autorreplicante y autorreferente en los memes: toda esa constelación acumulativa y no lineal de objetos digitales sociotécnicos y tecno-estéticos elaborados y compartidos colectivamente, que se replican de forma viral, pasan de una plataforma a otra, se recombinan y resignifican intertextualmente, para irradiar con humor y escenificar performativamente cierta idiotez colectiva en las redes sociales (Rowan, 2015, pp. 55-61). Por eso, los memes se han convertido en un medio decisivo para el troleo masivo en la esfera pública contemporánea.

\section{GUIONES SIMBÓLICOS DEL TROLEO COMO PRÁCTICA TRANSDISCURSIVA}

\subsection{La privatización de la bufonería}

Al referirse a las comunidades subculturales identificadas plenamente con la práctica estilizada del troleo, Phillips (2015) planteó que la subcultura de los troles refleja, de cierto modo, la cultura oficial, esto es, la explotación de la tragedia y de la indignación moral en los medios de comunicación: el troleo invertiría humorísticamente y volvería contra sí misma la lógica mediática sensacionalista -la mercantilización de las noticias y la capitalización de la atención- al embaucar y entrampar a otros usuarios de las redes sociales con bromas inverosímiles y exabruptos, por puro divertimento. Para Phillips (2015), aunque el troleo presenta muy diferentes variedades y propósitos, no deja de manifestar cierta significación política, pues estaría en juego una crítica de los medios masivos y la cultura oficial. Ciertamente, hay aspectos irritantes y desagradables en los mensajes misóginos y racistas de muchos troles, pero esa forma aberrante y obscena de la transgresión ayudaría a comprender los valores y sistemas normativos de la cultura hegemónica. Una práctica como el troleo patentizaría la dificultad a la hora de distinguir taxativamente lo bueno y lo malo, lo normal y lo anormal, lo aceptable y lo transgresor, pues estaríamos ante una manifestación ambivalente de las energías creativas e inventivas de las redes sociales que, no obstante, escenifica una parodia grotesca de valores culturales dominantes como la libertad de expresión.

En el marco de esa concepción de la práctica subcultural del troleo, Phillips compara la figura del trol con el personaje mítico del trickster, ese embaucador liminal, indeterminado, juguetón, burlón y creativo, que es tanto un astuto héroe cultural como un bufón egoísta descontrolado. En ese sentido, la autora retoma la sugerencia de Coleman (2012): el troleo se ha transformado en un conjunto de prácticas culturales audaces, incendiarias, bromistas y paródicas (frecuentemente orientadas a la autoafirmación polémica frente 
a los extraños a esa subcultura e, incluso, dirigidas a la victimización autocomplaciente por pura diversión), que entroncan con cierta tradición estética de la escenificación hiperbólica y la espectacularización de la transgresión, encarnada míticamente en la figura del trickster, ese ambiguo provocador e irreverente impugnador del orden establecido (Coleman, 2012, pp. 115-116). Según Phillips, pese a la diferencia práctica entre el mítico renovador cultural (el trickster) y el mundano comportamiento amoral del trol, realizado por pura diversión, ambos ilustrarían una función común: la ingesta oportunista de contenidos culturales para embaucar a la gente desprevenida mediante su juego grotesco (Phillips, 2015, pp. 1-10).

Quizá el trol evoque la función de un operador cultural del desbarajuste, míticamente encarnada por el trickster en el imaginario colectivo: se trataría de una figura que desordena las distinciones y las jerarquías culturales, mediante la indefinición, el exabrupto irrespetuoso y las humoradas sacrílegas. De esa manera, este personaje embaucador escenificaría la ambivalencia, la turbulencia, las transformaciones y el desorden en nuestros codificados universos culturales. Ahora bien, puesto que las funciones imaginarias se inscriben materialmente en prácticas culturales e instituciones sociales, resultaría más apropiado comparar al trol con el personaje del bufón, encarnación concreta de la ironía transgresora y la parodia irreverente que posibilita la canalización catártica del desorden y el mantenimiento del orden social. Como Balandier (1994) argumenta, los bufones ceremoniales de algunas tribus escenificaban ritual y cómicamente la irreverencia sacrílega, la obscenidad escandalosa y la desventura ridícula. De esa forma, los espectadores se confrontaban imaginariamente con los poderes establecidos y presenciaban la ruptura ambivalente del orden. Este tipo de bufón ritual (que libera vicariamente las transgresiones de las normas convencionales del orden establecido, para restaurar paródicamente el ordenamiento social) no se daría solo en sociedades exóticas o arcaicas, pues halla su análogo en el tradicional bufón de las cortes europeas. En tanto que operador del desorden, el bufón de la corte aparecía como doble coprotagonista del rey soberano: desde el seno de la institución política, desde la cercanía con los poderosos y desde los privilegios palaciegos, el personaje grotesco del bufón servía de contrapartida ridícula del poder y exhibía el reverso absurdo de la soberanía regia, su vanidad e insensatez (Balandier, 1994, pp. 52-58).

No obstante, hay algunas particularidades del bufón de corte que dificultan la comparación con el trol de las redes sociales. En primer lugar, el doble bufonesco del soberano tiene título de oficio, viste un uniforme y porta símbolos de su estatus, así como se destaca el hecho de que recibe una rigurosa formación, por parte de algún maestro que lo inicia en las artes musicales, poéticas, recitativas y cómicas. En segundo lugar, como maestro de la palabra y la diversión, el bufón puede decir la verdad sin máscaras ni tapujos y así contribuye a educar a los poderosos y a revelarles los reversos del poder, de modo que el soberano se ve ridículamente enfrentado a las fisuras, lagunas, intrigas y artificios de su posición soberana (Balandier, 1994, pp. 58-68). En contraste, ninguna de las condiciones anteriores se da en el trol.

Por eso, cabe concluir que el troleo en las redes sociales sería, a lo sumo, una forma de bufonería sin título de oficio, sin uniforme, sin formación rigurosa ni capacidad formativa. Podría considerarse una modalidad de bufonería privatizada y desregulada, ya que la iniciativa individual del trol no se asocia con una persona públicamente investida, notoria y autorizada, como lo era el bufón en la particular publicidad representativa escenificada en la corte del soberano - por utilizar la terminología de Habermas (2004, pp. 44-51)-; tampoco consiste en una función oficial con atribuciones, regulaciones y privilegios (un cargo designado, reconocido y financiado) en un escenario público-político como el de la corte del Antiguo Régimen. En ese sentido, el troleo resulta perfectamente funcional a la reproducción de la desregulación y fragmentación del vínculo social: la transgresión paródica que el trol despliega, por pura diversión, únicamente se daría como un emprendimiento anómico y autocomplaciente en el mercado digital de la atención y en una ultracompetitiva economía de la reputación, sin marcos normativos, jerarquías valóricas o estándares de prestigio compartidos. De esta forma, cualquier indicio de reconocimiento simbólico resulta deconstruido en el constante juego del basureo embaucador. 
Una interpretación reciente de los precedentes históricos del discurso odioso en las redes sociales llega a conclusiones semejantes. Según Korsten (2020), quizá los memes de Internet puedan haber heredado cierta función simbólica de figuras mitológicas como la divinidad Momo (otro operador cultural del desbarajuste destructor y creador, del enmascaramiento hipócrita y el desenmascaramiento crítico, de la falta de propósito y la transgresión) y su descendiente, la Fama, es decir, la veloz difusión de los rumores y las reputaciones. Si antiguamente se asociaba la veloz Fama a una voz divina que resultaba valiosa para las comunidades, en la moderna cultura de la imprenta y en los libelos de la primera modernidad se dio una transformación del rumor en cáustico discurso confrontacional, fácilmente reproducible al servicio de facciones religiosas y políticas que intentaban polarizar el debate público (Korsten, 2020).

Ahora bien, en el actual escenario del troleo en las redes sociales, el desenmascaramiento acelerado se habría desembarazado de cualquier vínculo con formas de discurso público que sustenten el vínculo social. El rumor insidioso operaría como un valor de cambio independiente, sin valor de uso o contenido significativo, únicamente al servicio de la acumulación de gratificación y de la distracción. Como práctica asociada a la capitalización socio-simbólica y a la aceleración de la acumulación de beneficio discursivo, el troleo resultaría funcional a la desregulación neoliberal que fragmenta los lazos sociales, gestiona las diferencias y mercantiliza cualquier significante cultural en desmedro de los lenguajes compartidos, las narrativas comunes, el discurso público y, en suma, la cultura, entendida como una trama compleja para cultivar los lazos comunitarios y reconocer simbólicamente nuestras diferencias (Korsten, 2020).

\subsection{La universalización de la calumnia}

En la bibliografía sobre el troleo, particularmente en las reflexiones de carácter jurídico, el fenómeno se asocia a la difamación y la calumnia en las redes sociales; no en vano, se ha acuñado un curioso término que refleja esta convergencia entre algunas plataformas de la comunicación mediada y el libelo difamatorio: Twibel, acrónimo formado con las palabras Twitter y libel (Placid et al., 2016). Aunque resulta problemática la imputación de un delito de difamación digital -debido a la borrosa línea que existe en Internet entre el medio de comunicación y la red social, entre la plataforma y las actividades de los usuarios, así como entre la libertad de expresión y la información de relevancia pública-, se han multiplicado los casos judiciales por troleo, mensajes ofensivos y daños a la honra en las redes sociales. Este nexo conceptual entre troleo y difamación lleva a preguntarse por las manifestaciones históricas de la calumnia que podrían constituir un precedente cultural de la figura del trol.

En la Antigua Grecia, existía un personaje protagónico en los litigios vejatorios: el sicofante, habitualmente descrito como el individuo que formula interesadamente acusaciones públicas y explota las leyes para procesar a otros ciudadanos y obtener recompensas pecuniarias de sus denuncias. A pesar de las descalificaciones del personaje en muchas fuentes clásicas (como alguien dañino, mentiroso, malicioso, fraudulento, codicioso, corrupto y chantajista), especialistas como Osborne (1990) han considerado que el sicofante era una figura relevante para el funcionamiento de la democracia ateniense. Mediante las acusaciones contra los privilegiados que rehusaban involucrarse en los asuntos comunes de la polis, el sicofante reivindicaría las inexcusables obligaciones y deberes de participar políticamente e incitaría a los ricos a arriesgar sus recursos al ingresar en la escena pública. Así pues, los alegatos del sicofante contribuirían polémicamente a la regulación social de la vida democrática, al desalentar la vida de privilegios, el disfrute privado de la riqueza y la falta de compromiso con las actividades públicas (Osborne, 1990).

No obstante, como ha objetado Harvey (1990), el sicofante que formulaba acusaciones infundadas era considerado un criminal y las definiciones legales del personaje lo presentan como alguien que -sin evidencia ni testigos- espera que el acusado le pague para no llegar al juicio. Además, la caracterización del sicofante se vincula a todo un vocabulario peyorativo (asociado a lo injusto, vergonzoso, impuro, desenfrenado, impostor, licencioso, maligno, difamatorio, cobarde, embaucador, falso, etc.) y a términos que lo acercan a los pícaros y 
ladrones, así como a expresiones que denotan una condición bestial y animal. En el vocabulario de las fuentes clásicas, el sicofante se perfilaba como una persona motivada por la ganancia monetaria con sus acusaciones, un formulador de falsos cargos y ataques difamatorios, un sofista embaucador, alguien consagrado a llevar a otros a juicio y rebuscar cargos sobre hechos pasados, sin que pueda evidenciarse algún tipo de impulso a la participación democrática, sino más bien el efecto de volver a los ricos contra el pueblo, generar división y desalentar la actividad política (Harvey, 1990).

Como puede apreciarse, estos precursores de la difamación pública han sido objeto de interpretaciones tan opuestas como nuestros troles digitales: también hay quienes ven en el troleo una labor crítica de incentivo para la participación polémica en la vida democrática, mientras que, en otros casos, se considera una fuente de fragmentación y falsificación del discurso público. Ahora bien, las acusaciones difamatorias del trol no se ejercen en el ámbito jurídico ni persiguen directamente un beneficio monetario, sino que se escenifican en las comunicaciones digitalmente mediadas y, básicamente, persiguen la capitalización de ventajas comparativas en el mercado simbólico de la reputación.

En su descripción de la cultura del Renacimiento en Italia, Burckhardt (1982) destacó la importancia de la maledicencia y el sarcasmo público en una forma de vida que exalta al individuo y sus pretensiones personales. Ilustró esta tendencia moderna con los pasquines de Pietro Aretino (todo un negocio de la difamación) y con el lujoso estilo de vida de este irreverente destructor de reputaciones, generosamente financiado por los poderosos que temían una pluma tan mordaz (pp. 130-134).

Por lo que respecta a las formas modernas de la calumnia en la cultura de la imprenta, Darnton (2014) ha descrito el funcionamiento de la industria editorial de la difamación política y todo el ambiente de los libelistas en la Francia prerrevolucionaria: el intercambio de rumores, chismes y caricaturas en los cafés y salones; la composición de libelos a partir de ese material y de otros libelos, por parte de comunidades de escritores bohemios en el exilio; la edición de libros prohibidos desde las imprentas británicas u holandesas; la circulación profusa en el mercado de los libros clandestinos; pero, también, los ofrecimientos y encargos para destruir reputaciones, los pagos a editores por no publicar libelos, o bien la colusión entre policía y libelistas para lucrasen con el negocio de la difamación. Según Darnton (2014), en la Francia prerrevolucionaria, la calumnia desempeñó una función decisiva y los libelos pasaron, progresivamente, de recoger anécdotas escandalosas sobre la corte, a denunciar la corrupción del régimen y el despotismo, cuestionar la legitimidad de la corona y desacralizar la figura del rey. En cualquier caso, desde las gacetas de anécdotas y novedades de la corte, hasta los numerosos libelos que desenmascaraban vidas privadas, la industria editorial de la difamación reprodujo una narrativa que reducía los complejos escenarios políticos a conflictos entre personalidades, maquinaciones personales y perversiones privadas. Esta personalización de la política distorsionaba la interpretación de los acontecimientos políticos y redefinía los equilibrios entre la esfera pública y el ámbito privado, al hacer público lo privado, exponer la intimidad y construir el discurso público a partir de las inmundicias de la vida privada (Darnton, 2014).

El paralelismo entre la moderna industria del libelo y el troleo en las redes sociales resulta ilustrativo: en ambos casos opera cierta economía de la reputación. No obstante, los libelos modernos formaban parte de una industria concentrada y relativamente regulada de la difamación, en la que se disputaba el capital simbólico de los notables de la corte y de la corona, mientras que la actividad del troleo parece reproducir una economía desregulada de capitalización autocomplaciente de reputación, en ausencia de portadores privilegiados de capital simbólico, a través de las comunicaciones digitalmente descentradas en unas redes sociales accesibles para cualquier usuario con conexión (Rosamond, 2020). La calumnia se ha vuelto universal: cualquiera la puede ejercer y todos pueden convertirse en sus víctimas, de manera que la personalización de la actividad pública se consuma como descrédito total, despolitización generalizada e impotencia para cuestionar a los poderes hegemónicos. 


\subsection{La democratización de la censura}

En la bibliografía sobre el discurso incendiario y hostil en las redes sociales, el troleo se ha asociado a una nueva forma de censura derivada del silencio autoimpuesto por temor a los comentarios ofensivos. Soto (2017) califica como poscensura a este recorte de la libre expresión por miedo a los ataques desmedidos de una multitud de desconocidos, sin necesidad de ortodoxia oficial ni aparatos represivos del Estado.

Soto (2017) considera que la hiperconexión en las redes sociales ha sobreexpuesto el ámbito de la intimidad en la esfera pública: todos los aspectos de la vida social se habrían tornado públicos y, al mismo tiempo, emocionales, como motivos para una autoexpresión desaforada, frecuentemente ofensiva y cargada de indignación moral. Además, con el descrédito de los medios de comunicación tradicionales y la irrupción de nuevos medios que replican los contenidos escandalosos, la difamación burda y los bulos de las redes sociales, la opinión pública se habría polarizado y crispado en extremo. Así, se ha engendrado una marcada fragmentación de la esfera pública por la intransigente guerra cultural de facciones con puntos de vista exacerbados y arrebatados, de modo que se impone el silencio de la poscensura. En ese contexto de troleos incendiarios entre discursos autorreferentes, las redes sociales se transformarían en un medio de vigilancia mutua, en el cual todos pueden ser celosos censores de las opiniones del resto, reaccionar airadamente e involucrarse en el ataque masivo de algún grupo de presión. Solo sacan partido de este escenario ciertos políticos populistas que se fortalecen con el escándalo y la polarización (Soto, 2017).

Este guion cultural de la poscensura por troleo quizá se puede inscribir en la historia de las instituciones tradicionales de la censura. En la bibliografía sobre la censura, se pueden reconocer las distintas formas que esta ha asumido tradicionalmente: la eliminación o intimidación de los autores; la destrucción de las obras; la elaboración de listas de obras prohibidas, que no se pueden publicar ni leer (como el Index Librorum Probibitorum); el control preventivo, para que no se produzcan materiales polémicos; la concesión por parte de las autoridades de licencias de publicación. Aunque también habría que considerar la censura ejercida por el mercado (al limitar la oferta de contenidos en virtud de la demanda consumista de entretenimiento y al generar concentración de los medios), o bien las nuevas formas de control del ciberespacio, tanto en nombre de la seguridad nacional como debido a la autocontención en nombre de lo políticamente correcto (Petley, 2009).

Ante la copiosa bibliografía sobre la censura, Müller (2004) ha discutido la posible distinción entre dos modalidades del fenómeno. En primer lugar, la censura regulativa se ejerce por parte de autoridades políticas, con el fin ideológico de conservar su poder a salvo de los cambios en la opinión pública (ya sea a través del control previo del material publicado y de la concesión de licencias, a través de la censura posterior a la publicación y la limitación de la distribución de las publicaciones cuestionadas, e incluso, mediante la autocensura). En segundo lugar, la censura constitutiva remitiría a las modalidades estructurales de producción de discurso (es decir, al orden del discurso, a las reglas de enunciación de cualquier formación discursiva, al control discursivo de lo que se puede decir y a las condiciones necesarias para la selección y formación del sujeto de la enunciación), de modo que no habría ninguna comunicación sin censura. Müller (2004) considera que este uso, demasiado amplio, del concepto de censura podría resultar contraproducente al volver ubicuo el fenómeno -ya que todo discurso estaría constitutivamente sujeto a la censura-, al dejar fuera de consideración al actor de la censura y al hacer equivalentes la censura y el control normativo de la comunicación.

Por eso, se propone una definición más acotada de la censura: se trata del control autoritario de los contenidos que se difunden en la esfera pública, ejercido por alguien distinto al emisor y al receptor de los mensajes. El control se da mediante la regulación oficial, institucionalización y administración de procedimientos de inspección, de manera que se proteja al público de influencias presuntamente perniciosas y se conforme una ortodoxia. En ese sentido, esta caracterización comunicativa de la censura presupondría la formación de cánones normativos de selección y estabilización de los contenidos culturales que la audiencia 
considera paradigmáticos (aunque no todo canon cultural involucra censura institucional por parte de personal autorizado ni prohibición estratégica de contenidos). Esta caracterización comunicativa de la censura permite concebir cierta semejanza de familia entre los fenómenos de control, que pueden afectar variablemente a la persona del emisor, al mensaje o texto, al código o estilo, al medio de comunicación o, también, al contexto de recepción (Müller, 2004, pp. 4-20).

Desde una perspectiva histórica, la función cultural de la censura ha experimentado transformaciones decisivas desde que el censor romano tuviese a su cargo no solo la elaboración del censo de la población, sino también la administración de la conducta moral del pueblo de Roma (Green y Karolides, 2005). Desde entonces, el término censura se asocia a cierto poder tutelar y prohibitivo para mantener un orden moral y brindar protección a los individuos, como si fuesen menores de edad o intelectualmente discapacitados. A través de la historia y de los distintos formatos de la comunicación humana, se habrían desplegado distintas formas de censura movidas por el temor de las autoridades a la exposición de contenidos culturales que resultaran amenazadores.

Inicialmente, la censura fue eminentemente política y sancionaba la traición al Estado y la sedición (más que la obscenidad o la pornografía). La primera forma de censura cultural puede atribuírsele quizá a la Iglesia católica, la cual expresaba un deseo de mantener el poder político y la verdadera fe, al suprimir la herejía; la creación de listas de libros prohibidos se basaba, pues, en una operación ideológica, aunque la labor de la Iglesia como árbitro de la moralidad pública extendió la censura a los pecados de la carne y la perversión de la conciencia. Con la pérdida de poder de la Iglesia, otras autoridades seculares, como las cortes de justicia, asumieron la labor de la censura y persecución de los libelos y otras publicaciones que amenazaban la paz social. En el curso de los siglos XVIII y XIX, irrumpió un estilo de censura puritana en el cual la moral privada proscribía las publicaciones por su obscenidad (más que por sus riesgos para el orden público) y las campañas filantrópicas de grupos de voluntarios de la sociedad civil apelaban a la educación decente del pueblo e imponían rígidamente su visión de la vida buena al resto. En ese sentido, la censura contemporánea parece haber desbordado la sensibilidad puritana; responde a imperativos de seguridad de la ciudadanía, así como a las restricciones del material publicable y de los contenidos culturales por temor a la subversión del orden familiar y gubernamental (Green y Karolides, 2005, pp. XVIII-XX).

Dentro de este panorama histórico de las formas culturales de la censura, la poscensura ejercida a través del troleo en las redes sociales se perfila como una modalidad de control comunicativo que opera sobre todos los factores del proceso de emisión de mensajes (mediante la descalificación del emisor, las invectivas contra el texto, la tutela de las plataformas, la impugnación del código y la manipulación estratégica del contexto de recepción). No obstante, no presupone un canon o un marco normativo definido, no persigue metas relacionadas con el régimen político, el orden público o la moral ciudadana, ni depende de la actuación de algún personal autorizado institucionalmente. La poscensura mediante el troleo le confiere la vigilancia a cualquiera que exprese arrebatadamente su indignación y solo responde a las peripecias de cierto combate por la capitalización autocomplaciente de reputación en una esfera pública fragmentada, sin otro propósito que el divertimento. Se trata, pues, de cierta democratización de la censura: un emprendimiento censor privado y emocional, no profesional ni ortodoxo, aunque sea a expensas del espacio público de nuestras democracias.

\subsection{La virtualización del linchamiento}

Ya el título del libro de Olabuenaga (2019), Linchamientos digitales, proporciona una pista para la interpretación práctica del troleo sobre determinado trasfondo histórico-cultural. Aunque, a veces, en la bibliografía especializada se emplean expresiones eufemísticas como online shaming (humillación digital) para describir el fenómeno, las redes sociales parecen haber revivido una versión de la ignominiosa actividad de tomarse la justicia por la propia mano sobre una víctima expiatoria y escenificar ejecuciones multitudinarias, preferentemente, de minorías excluidas. 
Con todo el significado simbólico que puede tener el espectáculo de la venganza colectiva extrajudicial y la expiación moral aleccionadora, el linchamiento provocaba cierta fascinación perturbadora en el público que concurría masivamente y tomaba fotografías del acontecimiento. Las redes sociales no constituyen una excepción, pues en ellas se amplifican, reproducen y comparten las publicaciones injuriosas y las expresiones arrebatadas de indignación moral airada, como otrora circulaban las postales de los linchamientos. En ese sentido, se puede afirmar que los linchamientos digitales son un contenido fácilmente comunicable y muy apreciado en las redes sociales. No solo llevan al extremo la violencia simbólica y la capacidad de las palabras para dañar y mortificar, sino que además reducen al silencio cualquier expresión de opiniones opuestas a las mayoritarias, por miedo a la exclusión social y el encono digital. A diferencia de los escándalos mediáticos (como puesta en escena de un ritual de absolución en que está en juego la reputación), el linchamiento digital lleva a cabo un ritual colectivo de ejecución en el cual la destrucción simbólica de la reputación comienza en el tribunal de indignación moral de las redes sociales y se reitera indefinidamente en Internet, pero continúa fácticamente en la vida real. Así, se distingue del mero ciberacoso o del troleo virtual que no se ejecuta fuera de las redes (Olabuenaga, 2019, pp. 257-261).

A la hora de retratar las dinámicas de masas y el comportamiento de las muchedumbres en los linchamientos digitales, Olabuenaga (2019, pp. 229-231) recurre a los planteamientos de Canetti (1987) en Masa y poder. Ciertamente, para Canetti (1987), uno de los primordiales comportamientos masivos consiste en las masas de acoso, derivadas de las arcaicas partidas de caza. Estas masas de acoso se concentran en dar muerte a la víctima impotente para, posteriormente, desintegrarse y dispersarse como masa en fuga. De ahí la necesidad de que se repita la dinámica de acoso colectivo para mantener cohesionada la masa (por medio de ejecuciones públicas, por ejemplo). Y es que, además del asilamiento, la expulsión o la separación de la víctima -así entregada a la muerte-, la masa de acoso dispone de la opción del asesinato colectivo (la lapidación, la quema o alguna otra forma de matar al condenado), que es, en última instancia, la base de toda modalidad de ejecución pública, en la cual la multitud funge simultáneamente como juez, verdugo y espectador. Según Canetti (1987), aunque hoy en día parezca haberse extendido la aversión a matar colectivamente, la prensa escrita proporcionaría un refugio para participar en ejecuciones públicas. Se trataría de un público de lectores, una masa que no necesita reunirse, una multitud distanciada de los acontecimientos e irresponsable, aunque tan estable y recurrente como el periódico que la divierte repetidamente cada día (Canetti, 1987, pp. 43-47). Obviamente, se podría concluir que el troleo digital y el ciberacoso en las redes sociales amplifican y llevan al paroxismo esa capacidad que tiene la prensa periódica para reiterar cierta participación cotidiana en un espectáculo diario de ajusticiamiento público victimizador.

En rigor, el linchamiento digital parece relacionarse más directamente con modalidades arcaicas de la pena, basadas en la atribución de responsabilidad colectiva y en la transmisión de la culpabilidad, en las formas sustitutivas de sanción y en ciertos mecanismos simbólicos de imputación. Como ilustran algunas formas de troleo y ciberacoso, el enjuiciamiento en las redes sociales parece remitir a primitivas prácticas penales: la profanación de los difuntos, así como los actos punitivos en contra de la reputación de los muertos; la pena en efigie, esto es, la sanción ejecutada simbólicamente sobre imágenes de las personas; la expulsión o proscripción; el castigo sobre chivos expiatorios que permitan desviar el mal; las penas imaginarias de muerte ejercidas mediante la eficacia simbólica de la maldición; por último, las penas infamantes, como el castigo en la piedra de la vergüenza, la exposición en la picota o la marca a fuego (Von Hentig, 1967). Al fin y al cabo, en cuanto fenómeno penal histórico, el linchamiento se perfila como una forma de cuasi-enjuiciamiento, pues irrumpe cuando la justicia estatal no cumple adecuadamente su función y consiente la venganza colectiva, de manera que la pena de muerte se aplica por encima de la ley y el instinto de las masas se vuelca sin formalismos contra cierto enemigo a eliminar (Von Hentig, 1968, pp. 75-77).

En cualquier caso, el troleo parece compartir una característica decisiva con la práctica histórica del linchamiento: en ambos, el enemigo sobre el cual se concentra el cuasi-enjuiciamiento suele ser alguna minoría marcada por su raza, cultura o género. En efecto, como han puesto de manifiesto las investigaciones 
sobre la práctica del linchamiento en Estados Unidos (en un escenario decimonónico de profesionalización de la justicia, procesamiento criminal público y reforma penal), el recurso a la violencia colectiva letal no sancionada por la ley no solo eludía las reformas legales que hubieran permitido garantizar efectivamente la imparcialidad legal y proteger los derechos de los desaventajados, sino que además resultaba funcional a la reproducción de la desigualdad racial o de clase y contribuía a la legitimación del orden social y comunitario establecido (Pfeifer, 2011, pp. 1-5). Así como las víctimas primordiales del linchamiento eran esclavos, afroamericanos, nativos, mexicanos y trabajadores temporeros, en el cuasi-enjuiciamiento digital hay un perfil característico de los objetivos del troleo: grupos desaventajados de la sociedad, en virtud de su condición de género, de su adscripción étnica o de alguna afiliación religiosa o ideológica minoritaria.

\subsection{La hibridación del conflicto}

En numerosos informes de organismos militares y de agencias no gubernamentales, hay referencias a tropas o brigadas de troles. De este modo, se introduce un marco interpretativo del troleo como estrategia bélica orquestada bajo la premisa de la militarización de las redes sociales. En algunos informes se describe la actividad de auténticas cibertropas, esto es, de equipos -organizados por gobiernos, ejércitos o partidos políticos- para manipular la opinión pública en Internet y convertir en un arma las redes sociales (Bradshaw y Howard, 2017).

Dentro del repertorio de estrategias, herramientas y técnicas que estas cibertropas emplearían para la manipulación de las redes sociales, se menciona tanto el empleo de lenguaje progubernamental y la propaganda a favor de las posiciones oficiales como el troleo, el acoso y las amenazas dirigidas a los opositores. Las cibertropas suelen involucrarse estratégicamente en la producción de comentarios de apoyo a la ideología del régimen y en la publicación de contenidos negativos contra los opositores políticos, aunque también generan contenidos neutrales para distraer la atención o desviar el tema de discusión. Cuando se recurre al troleo y al acoso digital, las cibertropas han de perfilar al individuo o colectivo contra el cual se dirige el lenguaje ofensivo (normalmente con el propósito de acallar el disentimiento en las redes sociales); de igual manera, pueden recurrir a cuentas falsas para enmascarar sus identidades, así como a bots o programas informáticos que multiplican la influencia de las publicaciones en las plataformas de Internet (Bradshaw y Howard, 2017).

Según algunos informes militares (NATO Strategic Communications Centre of Excellence, 2016), la instrumentalización de las redes sociales como arma de los nuevos conflictos políticos y desafíos geopolíticos genera un nuevo panorama denominado guerras híbridas. Se trata de un escenario que combina -de forma compleja, variable e indefinida- diversos métodos no convencionales de inteligencia para someter al adversario: las formas de guerra psicológica para influir en los sistemas de creencias, valores y motivaciones de las poblaciones objetivo, o bien la guerra de información para obtener el apoyo de la opinión pública o desacreditar la ideología del adversario. En ese sentido, las agencias de inteligencia convierten las redes sociales en un arma poderosa, continuamente operativa, difícil de detectar e identificar, así como capaz de intervenir a bajo costo en todos los niveles de la sociedad y sobre un amplio público.

Entre las estrategias disponibles para la manipulación de masas y el control de la narrativa pública en esta militarización de los medios digitales figuran la creación de identidades falsas, la difusión de bulos, la desinformación, el lenguaje ofensivo, la provocación y el troleo. Ahora bien, el troleo orquestado e ideológicamente dirigido en la guerra híbrida se aleja de la práctica clásica del trol de Internet (ese comportamiento digital delusorio y disruptivo que solo perseguía provocar, humillar y perturbar en las redes sociales por pura diversión). Por eso, se designa como troleo hibrido a la modalidad constante, sistemática y organizada de desinformación, difusión de teorías conspiratorias y empleo de lenguaje negativo para amenazar y acallar a los opositores. Como actores de la guerra híbrida, los troles híbridos instrumentalizan estratégicamente los roles y reglas de Internet al servicio de objetivos de guerra informacional orquestados 
gubernamentalmente contra los opositores (NATO Strategic Communications Centre of Excellence, 2016, pp. 7-11).

Sin duda, esta práctica de troleo híbrido en un contexto de instrumentalización armamentista de las redes sociales esboza un nuevo modo de entender culturalmente el conflicto. Según Huizinga (1987), la concepción tradicional de la guerra incorporaba un componente sacral, ceremonioso y ritual, así como cierta superfluidad improductiva, propia de una actividad lúdica. En suma, la guerra se inscribía en las actividades agonales de competencia regulada, en las cuales se confunden juego y lucha. Como función cultural, la guerra agonal suponía algunas reglas limitadoras, la separación de la guerra y la paz, el tratamiento del adversario como ser humano y el reconocimiento de las pretensiones de los contendientes a hacer valer cierto derecho o, simplemente, a ganar el honor y la gloria reservada para el victorioso. En el campo de la guerra agonal, se cultivó el honor, la valentía, la cortesía, el autodominio y la lealtad; es decir, se elaboraron valores civilizatorios como parte de un noble juego cultural codificado normativamente y virtuoso en potencia. Sin embargo, según Huizinga (1987), la guerra habría perdido su carácter lúdico y agonal cuando las partes o facciones beligerantes se limitaron a autoafirmar arbitrariamente su poder, con el único objetivo de ganar a toda costa y sin límites en una lucha sin cuartel. En ese momento, se desdibujó la regulación ceremonial de la guerra y se cuestionó el reconocimiento humanitario del adversario y de cualquier clase de vínculo jurídico, como ha ocurrido en la moderna teoría de la guerra total (Huizinga, 1987, pp. 109-127).

En esa historia de liquidación de la función cultural y la regulación simbólica del conflicto bélico, la guerra híbrida abre un escenario aún más inquietante: la absoluta desregulación del conflicto, debido al recurso instrumental de métodos no convencionales y no identificables; la expansión indistinta e indefinida del antagonismo a través de todos los ámbitos de la vida social, sin excepción; la militarización estratégica incluso de los medios de comunicación, las redes sociales y los ámbitos de exposición de la intimidad. Ahora bien, cuando la guerra pierde definitivamente su elemento agonístico, no solo se desvanece cualquier posibilidad de reconocimiento civilizado de las pretensiones y derechos del contendiente, sino que también se vuelve imposible esa transformación del antagonismo en agonismo -o bien del enemigo en adversario- que es constitutiva de lo político y de la actividad política en la esfera pública (Mouffe, 2009).

\section{Conclusión: LA DiALÉCTiCA MORAL Del TROLEO}

Al interpretar el troleo como una práctica transdiscursiva, resulta posible develar guiones simbólicos, tramas culturales y tradiciones históricas a los cuales este fenómeno remite intertextual e interdiscursivamente. En este trabajo se han reconocido algunos de los marcos de comprensión con los que el troleo parece establecer cierta relación de transmisión, relevo, canalización versionada, reapropiación y transformación cultural. En primer lugar, como se plantea en algunas interpretaciones del fenómeno, el componente paródico e irónico de esta práctica disruptiva y delusoria, ejercida en algunas plataformas de comunicación digital supuestamente, por pura diversión-, recogería cierta función simbólica de operador del desorden cultural, otrora representada en la figura mítica del trickster y concretamente institucionalizada en el insolente bufón de la corte real. En segundo lugar, la práctica del troleo guardaría continuidad cultural con las modalidades históricas de expresión de la calumnia y la difamación, como los sicofantes del mundo antiguo o los modernos libelistas. En tercer lugar, este fenómeno de expresión arrebatada de furia moral en las redes sociales podría constituir una variante nueva de ejercicio de la censura social, la poscensura, en cierto modo vinculada con las formas tradicionales de la censura política, religiosa, cultural y, sobre todo, con una modalidad paroxística y desencantada de censura moral puritana. En cuarto lugar, el troleo reviviría digital y virtualmente algunos procedimientos arcaicos de atribución de culpa colectiva y asignación simbólica de la pena, aunque particularmente se vincularía con cierta modalidad de ajusticiamiento simbólico al margen de la ley en las redes sociales. Por último, con la instrumentalización armamentista de las redes sociales por parte de ejércitos de troles (orquestados gubernamentalmente para combatir la disidencia), se abriría un 
nuevo escenario en la historia cultural de la guerra: el conflicto híbrido, indeterminado, desregulado y no convencional.

El anudamiento entre estas hebras simbólicas, hilos culturales y continuidades históricas (la privatización de la parodia, la universalización de la calumnia, la democratización de la censura, la virtualización del linchamiento y la hibridación del conflicto) no pasaría simplemente por la yuxtaposición formal o la solidaridad contingente de las distintas facetas del troleo. En principio, cabe reconocer cierto nexo dialéctico y toda una dinámica orgánica en las diferentes manifestaciones del troleo en las redes sociales. Al parecer, se trataría de una práctica y un modo de subjetivación profundamente escindida y fragmentada, irreversiblemente sumida en su propia contradicción, tan alienada que resulta incapaz de concebir su propio trasfondo y tan impotente que no logra articular ningún proyecto cultural constructivo y potencialmente emancipador.

En ese sentido, los actos disruptivos y la provocación arbitraria del trol caracterizarían a una forma de conciencia y un modo de subjetivación radicalmente dependiente, cuyo reverso consistiría en la acusación dudosa y la respuesta difamatoria por parte de algún otro. A su vez, la expresión indeterminada y calumniosa de una furia moral arrebatada conduciría a escenarios de pánico moral como los que conceptualizó sociológicamente Cohen (2002), caracterizados por una difusa preocupación masiva ante una supuesta amenaza, la cual genera reacciones desproporcionadas y volátiles de imputación, hostilidad y demonización (pp. XVI-XVII). Todo este juego de enjuiciamiento y acusación infundada se traduciría en un silenciamiento generalizado, esto es, en una censura difusa sin contenido normativo ni autoridad simbólica. Este acallamiento temeroso, inducido por la generalización de la acusación infundada, solo se reproduciría en la medida en que se escenifica reiteradamente el cuasi-enjuiciamiento en las redes sociales y, de modo periódico, se lincha digitalmente a alguna víctima propiciatoria. El escenario de provocaciones interminables, acusaciones indeterminadas, censura anónima y hostilidad vicaria restitutiva se consumaría cuando el anonimato del troleo y del acoso digital se instrumentaliza como arma de un tipo de conflicto desregulado, sin limitaciones ni marcos normativos.

Se podría considerar que la práctica del troleo y la subjetividad del trol no son sino una versión digitalmente mediada de las contradicciones insalvables inherentes a la convicción moral desaforada, cuyo despliegue dialéctico expuso Hegel (1985; 1988). Así, la autoexpresión de la certeza moral y la conciencia satisfecha de sí misma se enuncian inevitablemente en el lenguaje de la hipocresía y la extrema escrupulosidad, que solo disfrazan -bajo la máscara de la universalidad y la pureza- las motivaciones particulares y arbitrarias por el afán de reconocimiento. Ahora bien, el prurito por desenmascarar las motivaciones impuras de los demás y la denuncia de la hipocresía ajena por parte de una conciencia moralmente enjuiciadora solo encubren -vil y malintencionadamente- los propios intereses y la propia hipocresía. Finalmente, la convicción moral desaforada y la hipocresía redoblada desembocan en el conflicto desgarrador de los intransigentes enjuiciamientos recíprocos, sin perspectiva de reconciliación (Hegel, 1985, pp. 385-390). Como colofón, al autoafirmarse bajo la forma de una certeza subjetiva arbitraria sin horizonte normativo compartido ni significado universal alguno, la convicción moral conduce a esa modalidad de conciencia irónica que juega caprichosamente con todo valor y devalúa cualquier contenido ético, por pura vanidad subjetiva y para el gozo de uno mismo (Hegel, 1988, pp. 217-221).

En el trol de las redes sociales, se vería consumado digitalmente todo este plexo de motivaciones caprichosas contradictorias: la vana conciencia irónica, la arbitrariedad subjetiva, los arrebatos de convicción moral hipócrita y el enjuiciamiento moral desaforado. Las implicaciones no podrían ser más calamitosas, como argumentan Singer y Brooking (2018):

No hay duda de que el troleo hace que Internet sea un lugar peor. El troleo tiene como objetivo los medios vitales y arruina vidas. Silencia las voces y empuja a la gente a esconderse, reservando una crueldad especial para las mujeres y las minorías raciales. Incluso aquellos que escapan de la ira de los troles deben enfrentarse a un entorno digital que amplifica la indignación 
y silencia efectivamente todo lo demás. El poder de los troles -que realmente representa el poder de la ira- transforma Internet en una ciénaga cáustica y tóxica (p. 165).

Pero, ¿solamente Internet se está convirtiendo en un medio tóxico y en un entorno inhabitable, debido a la acción de los troles en las redes sociales?

\section{REFERENCIAS BIBLIOGRÁFICAS}

Asenas, J. J. y Hubble, B. (2018). Trolling Free Speech Rallies: Social Media Practices and the (Un)Democratic Spectacle of Dissent. Taboo: The Journal of Culture and Education, 17(2), 36-53. https://digitalcommons.lsu.e $\mathrm{du} / \mathrm{taboo} / \mathrm{vol} 17 / \mathrm{iss} 2 / 6$

Balandier, G. (1994). El poder en escenas. Paidós.

Berghel, H. y Berleant, D. (2018). The Online Trolling Ecosystem. Computer, 51(8), 44-51. https://doi.org/10.110 9/MC.2018.3191256

Bishop, J. (2013). The Art of Trolling Law Enforcement: A Review and Model for Implementing 'Flame Trolling' Legislation Enacted in Great Britain (1981-2012). International Review of Law, Computers \& Technology, 27(3), 301-318. https://doi.org/10.1080/13600869.2013.796706

Bishop, J. (2014). Representations of 'Trolls' in Mass Media Communication: A Review of Media-texts and Moral Panics Relating to 'Internet Trolling'. International Journal of Web Based Communities, 10(1), 7-24. https://d oi.org/10.1504/IJWBC.2014.058384

Bradshaw, S. y Howard, P. N. (2017). Troops, Trolls and Troublemakers: A Global Inventory of Organized Social Media Manipulation. University of Oxford. https://demtech.oii.ox.ac.uk/wp-content/uploads/sites/89/2017/07/ $\operatorname{Tr}$ oops-Trolls-and-Troublemakers.pdf

Buckels, E. E., Trapnell, P. D. y Paulhus, D. (2014). Trolls Just Want to Have Fun. Personality and Individual Differences, 67, 97-102. doi:10.1016/j.paid.2014.01.016

Buckels, E. E., Trapnell, P. D., Andjelovic, T. y Paulhus, D. (2019). Internet Trolling and Everyday Sadism: Parallel Effects on Pain Perception and Moral Judgment. Journal of Personality, 87, 328-340. https://doi.org/10.1111 /jopy. 12393

Burckhardt, J. (1982). La cultura del Renacimiento en Italia. EDAF.

Calvo, E. y Aruguete, N. (2020). Fake news, trolls y otros encantos. Siglo XXI.

Canetti, E. (1987). Masa y poder. Alianza Editorial.

Clucas, T. (2020). 'Don't Feed the Trolls'. Social Media and the Limits of Free Speech. En S. Polak y D. Trottier (Eds.), Violence and Trolling on Social Media (pp. 47-63). Amsterdam University Press.

Cohen, S. (2002). Folk Devils and Moral Panics. Routledge.

Coleman, E. G. (2012). Phreaks, Hackers, and Trolls: The Politics of Transgression and Spectacle. En M. Mandiberg (Ed.), The Social Media Reader (pp. 99-119). New York University Press.

Coles, B. A. y West, M. (2016). Trolling the Trolls: Online Forum Users Constructions of the Nature and Properties of Trolling. Computers in Human Behavior, 60, 233-244. https://doi.org/10.1016/j.chb.2016.02.070

Cruz, A. G. B., Seo, Y. y Rex, M. (2018). Trolling in Online Communities: A Practice-based Theoretical Perspective. The Information Society, 34(1), 15-26. https://doi.org/10.1080/01972243.2017.1391909

Darnton, R. (2014). El diablo en el agua bendita o el arte de la calumnia de Luis XIV a Napoleón. Fondo de Cultura Económica.

De Certeau, M. (2007). La invención de lo cotidiano I. Artes de hacer. Universidad Iberoamericana.

Dynel, M. (2016). "Trolling is not Stupid": Internet Trolling as the Art of Deception Serving Entertainment. Intercultural Pragmatics, 13(3), 353-381. https://doi.org/10.1515/ip-2016-0015

Fairclough, N. (1992). Discourse and Social Change. Polity Press. 
Fernández-Ríos, L. y Buela-Casal, G. (2009). Standards for the Preparation and Writing of Psychology Review Articles. International Journal of Clinical and Health Psychology, 9(2), 329-344. https://psycnet.apa.org/record/2009-0 5776-008

Fichman, P. y Sanfilippo, M. R. (2016). Online Trolling and Its Perpetrators. Rowman \& Littlefield.

Genette, G. (1989). Palimpsestos. Taurus.

Green, J. y Karolides, N. J. (2005). Encyclopedia of Censorship. Facts On File, Inc.

Habermas, J. (1999). Teoría de la acción comunicativa I. Racionalidad de la acción social y racionalización social. Taurus.

Habermas, J. (2004). Historia y critica de la opinión pública. Gustavo Gili.

Hannan, J. (2018). Trolling Ourselves to Death? Social Media and Post-truth Politics. European Journal of Communication, 33(2), 214-226. https://doi.org/10.1177/0267323118760323

Hardaker, C. (2010). Trolling in Asynchronous Computer-mediated Communication: From User Discussions to Academic Definitions. Journal of Politeness Research, 6(2), 215-242. https://doi.org/10.1515/JPLR.2010.011

Harvey, D. (1990). The Sykophant and Sykophancy: Vexatious Redefinition? En P. Cartledge, P. Millett y S. Todd (Eds.), Nomos. Essays in Athenian Law, Politics and Society (pp. 103-122). Cambridge University Press.

Hegel, G. W. F. (1985). Fenomenología del espiritu. Fondo de Cultura Económica.

Hegel, G. W. F. (1988). Principios de la filosofía del derecho. EDHASA.

Hopkinson, C. (2013). Trolling in Online Discussions: From Provocation to Community-Building. Brno Studies in English, 39(1), 5-25. doi:10.5817/BSE2013-1-1

Huizinga, J. (1987). Homo ludens. Alianza Editorial.

Korsten, F.W. (2020). Historical Prefigurations of Vitriol Communities, Constituencies and Plutocratic Insurgency. En S. Polak y D. Trottier (Eds.), Violence and Trolling on Social Media (pp. 87-108). Amsterdam University Press.

March, E. (2019). Psychopathy, Sadism, Empathy, and the Motivation to Cause Harm: New Evidence Confirms Malevolent Nature of the Internet Troll. Personality and Individual Differences,141, 133-137. https://doi.org/ 10.1016/j.paid.2019.01.001

March, E. y Marrington, J. M. (2019). A Qualitative Analysis of Internet Trolling. Cyberpsychology, Behavior, and Social Networking, 22(3), 192-197. https://doi.org/10.1089/cyber.2018.0210

McCosker, A. (2014). Trolling as Provocation: YouTube's Agonistic Publics. Convergence: The International Journal of Research into New Media Technologies, 20(2), 201-217. https://doi.org/10.1177/1354856513501413

Mouffe, C. (2009). En torno a lo político. Fondo de Cultura Económica.

Müller, B. (2004). Censorship and Cultural Regulation: Mapping the Territory. En B. Müller (Ed.), Censorship \& Cultural Regulation in the Modern Age (pp. 1-31). Editions Rodopi B.V.

Mylonas, Y. y Kompatsiaris, P. (2021). Trolling as Transgression: Subversive Affirmations Against Neoliberal Austerity. International Journal of Cultural Studies, 24(1), 34-55. doi:10.1177/1367877919891

Nagle, A. (2018). Muerte a los normies. Orciny Press.

NATO Strategic Communications Centre of Excellence. (2016). Internet Trolling as a Hybrid Warfare Tool: The Case of Latvia [Informe de investigación]. NATO. https://www.stratcomcoe.org/internet-trolling-hybrid-warfare-t ool-case-latvia-0

Noble, W. (2017). Trolling, the Ugly Face of the Social Network. En T. Owen, W. Noble y F. C. Speed (Eds.), New Perspectives on Cybercrime (pp. 113-139). Palgrave Macmillan. https://doi.org/10.1007/978-3-319-53856-3_7

Olabuenaga, A. M. (2019). Linchamientos digitales. Paidós.

Ortiz, S. M. (2020). Trolling as a Collective Form of Harassment: An Inductive Study of How Online Users Understand Trolling. Social Media + Society (April-June), 1-9. https://doi.org/10.1177/205630512092851

Osborne, R. (1990). Vexatious Litigation in Classical Athens: Sykophancy and the Sykophant. En P. Cartledge, P. Millett y S. Todd (Eds.), Nomos. Essays in Athenian Law, Politics and Society (pp. 83-102). Cambridge University Press. 
Dr. Juan Antonio González de ReQuena Farré. La filosofía del troleo: una revisión interpretativa

Petley, J. (2009). Censorship. A Beginner's Guide. Oneworld Publications.

Pfeifer, M. J. (2011). The Roots of Rough Justice: Origins of American Lynching. University of Illinois Press.

Phillips, W. (2015). This Is Why We Can't Have Nice Things: Mapping the Relationship Between Online Trolling and Mainstream Culture. The MIT Press.

Placid, R., Wynekoop, J.y Feicht, R. W. (2016). Twibel: The Intersection of Twitter and Libel. The Florida Bar Journal, 90(8), 32-39. https://www.floridabar.org/the-florida-bar-journal/twibel-the-intersection-of-twitter-and-libel/

Polak, S. y Trottier, D. (Eds.). (2020). Violence and Trolling on Social Media. Amsterdam University Press.

Rosamond, E. (2020). From Reputation Capital to Reputation Warfare: Online Ratings, Trolling, and the Logic of Volatility. Theory, Culture \& Society, 37(2), 105-129. doi:10.1177/0263276419872530

Rowan, J. (2015). Memes. Inteligencia idiota, politica rara y folclore digital. Capitán Swing.

Searle, J. (1997). La construcción de la realidad social. Paidós.

Singer, P. W. y Brooking, E. T. (2018). LikeWar: The Weaponization of Social Media. Houghton Mifflin Harcourt.

Snyder, H. (2019). Literature Review as a Research Methodology: An Overview and Guidelines. Journal of Business Research, 104, 333-339. doi:10.1016/j.jbusres.2019.07.039

Soto, J. (2017). Arden las redes. La postcensura y el nuevo mundo virtual. Debate.

Von Hentig, H. (1967). La pena I. Formas primitivas y conexiones histórico-culturales. Espasa-Calpe.

Von Hentig, H. (1968). La pena II. Las formas modernas de aparición. Espasa-Calpe.

Wallace, P. (2016). The Psychology of the Internet. Cambridge University Press. 